24 Lyketsos CG, Sheppard JM, Steinberg M, Tschanz JA, Norton MC, Steffens DC et al. Neuropsychiatric disturbance in Alzheimer's disease clusters into three groups: the Cache County study. Int J Geriatr Psychiatry 2001; 16: 1043-53.

25 Mcllroy S, Craig D. Neurobiology and genetics of behavioural syndromes of Alzheimer's disease. Curr Alzheimer Res 2004; 1: 135-42.

26 Ropacki SA, Jeste DV. Epidemiology of and risk factors for psychosis of Alzheimer's disease: a review of 55 studies published from 1990 to 2003. Am J Psychiatry 2005; 162: 2022-30.

27 Ballard C, Bannister C, Solis M, Oyebode F, Wilcock G. The prevalence, associations and symptoms of depression amongst dementia sufferers. J Affect Disord 1996; 36: 135-44.

28 Alexopoulos GS, Meyers BS, Young RC, Campbell S, Silbersweig D, Charlson M. 'Vascular depression' hypothesis. Arch Gen Psychiatry 1997; 54: 915-22.

29 Treiber KA, Lyketsos CG, Corcoran C, Steinberg M, Norton M, Green RC, et al. Vascular factors and risk for neuropsychiatric symptoms in Alzheimer's disease: the Cache County Study. Int Psychogeriatr 2008; 20: 538-53.

30 Pritchard AL, Harris J, Pritchard CW, Coates J, Haque S, Holder R, et al. The effect of the apolipoprotein $\mathrm{E}$ gene polymorphisms and haplotypes on behavioural and psychological symptoms in probable Alzheimer's disease. J Neurol Neurosurg Psychiatry 2007; 78: 123-6.

31 Aalten $P$, de Vugt ME, Lousberg R, Korten E, Jaspers N, Senden B, et al. Behavioral problems in dementia: a factor analysis of the neuropsychiatric inventory. Dement Geriatr Cogn Disord 2003; 15: 99-105.

32 Aarsland D, Bronnick K, Ehrt U, De Deyn PP, Tekin S, Emre M, et al. Neuropsychiatric symptoms in patients with Parkinson's disease and dementia: frequency, profile and associated care giver stress. J Neurol Neurosurg Psychiatry 2007; 78: 36-42.
33 Amer-Ferrer G, de la Pena A, Garcia Soriano MT, Garcia Martin A. Main components of Neuropsychiatric Inventory in Alzheimer's disease. Definition of behavioral syndromes [Spanish]. Neurologia 2005; 20: 9-16.

34 Zuidema SU, de Jonghe JF, Verhey FR, Koopmans RT. Neuropsychiatric symptoms in nursing home patients: factor structure invariance of the Dutch nursing home version of the neuropsychiatric inventory in different stages of dementia. Dement Geriatr Cogn Disord 2007; 24: 169-76.

35 Moran M, Walsh C, Lynch A, Coen RF, Coakley D, Lawlor BA. Syndromes of behavioural and psychological symptoms in mild Alzheimer's disease. Int $J$ Geriatr Psychiatry 2004; 19: 359-64.

36 Ballard CG, O'Brien JT, Swann AG, Thompson P, Neill D, McKeith IG. The natural history of psychosis and depression in dementia with Lewy bodies and Alzheimer's disease: persistence and new cases over 1 year of followup. J Clin Psychiatry 2001; 62: 46-9.

37 Stavitsky K, Brickman AM, Scarmeas N, Torgan RL, Tang MX, Albert M, et al. The progression of cognition, psychiatric symptoms, and functional abilities in dementia with Lewy bodies and Alzheimer disease. Arch Neurol 2006; 63 1450-6.

38 Starkstein SE, Mizrahi R, Garau L. Specificity of symptoms of depression in Alzheimer disease: a longitudinal analysis. Am J Geriatr Psychiatry 2005; 13 802-7.

39 Pathological correlates of late-onset dementia in a multicentre, communitybased population in England and Wales. Neuropathology Group of the Medical Research Council Cognitive Function and Ageing Study (MRC CFAS). Lancet 2001; 357: 169-75.

\title{
Why borderline baulks mainstream psychiatry
}

Medical and psychiatric treatments contain three indispensable components: a therapeutic relationship, meaning-making and changepromotion. For people who have borderline personality disorder each is problematic. Relationships are chaotically sought or fled from; meaning equates to control or irrelevancy; naive attempts at change invalidate precarious defensive 'solutions' to despair or overwhelming affect, such as self-harm or addiction. Conventional approaches thus typically exacerbate rather than alleviate distress. Effective treatments for borderline personality disorder: tolerate and target disruptions to the therapeutic relationship; start from the client's own meaning structures before co-constructing new ones; and validate while simultaneously introducing changes in thought patterns and behaviour. 